\title{
An overview of allergic and bacterial conjunctivitis
}

\author{
N Schellack, N Shirindza, T Mokoena
}

School of Pharmacy, Faculty of Health Sciences, Sefako Makgatho Health Sciences University, South Africa

Corresponding author, email: natalie.schellack@smu.ac.za

Conjunctivitis affects many people across the globe, significantly disturbing the quality of life of the people who are affected. Conjunctivitis can be divided into infectious and noninfectious causes. Viruses and bacteria are the most common infectious causes. Some of the most commonly diagnosed allergic diseases include atopic dermatitis, rhinitis, allergic conjunctivitis and sinusitis. Other conditions, such as eosinophilic oesophagitis, the prevalence of which is on the rise, are being diagnosed across all continents, except for Africa.

Allergic conjunctivitis is an allergic disease characterised by inflammation of the conjunctiva caused by airborne allergens; it presents as itching, excessive lacrimation, discharge and pink eye. Usually it is associated with other allergic conditions such as allergic rhinitis and bronchial asthma. Allergic conjunctivitis is further divided into acute, seasonal allergic conjunctivitis (SAC) and perennial allergic conjunctivitis (PAC). Bacterial conjunctivitis, caused by bacterial and viral pathogens, may include three major categories: hyperacute bacterial conjunctivitis, acute conjuncitivis and chronic conjunctivitis. The diagnosis is primarily clinical.

This article provides an overview of these conditions and their current management options.

Keywords: allergic disease, antihistamine, anaphylaxis, atopy, atopic march, rhinitis, sinusitis

\section{Introduction}

Allergic diseases are complex diseases caused by a combination of genetic and environmental factors. Allergic diseases are on the increase, affecting approximately $30 \%$ to $40 \%$ of the world's population. They decrease quality of life and may have an immense influence on personal, social, and economic costs. ${ }^{1}$

An allergic response is a hypersensitivity reaction mediated by the adaptive immune system. The presence of a trigger, such as an allergen or antigen, induces a humoral immunological response, which in turn initiates a complex immunological reaction. This dysregulation in the immune function elevates the plasma levels of immunoglobulin $E(\lg E)$. The release of $\lg E$ is followed by binding to the allergen or antigen, which in turn stimulates the mast cells to degranulate and release several proinflammatory substances that include histamine, chemokines and numerous cytokines. ${ }^{2}$

There are many different factors that come into play when searching for the causative agent of allergy. Environmental influences that occur in pregnancy and early childhood can alter the physiological, immune, structural and behavioural development and thus transform response patterns that influence susceptibility to future diseases. ${ }^{3}$ Genetics also play a vital role in the susceptibility of an individual to an allergic disease. The most common allergic conditions around the world include atopic dermatitis, rhinitis, asthma, rhinosinusitis, allergic conjunctivitis and, most recently, allergic oesophagitis., ${ }^{3,4}$ Allergic conjunctivitis is primarily a condition that affects young adults, with the average age of onset being 20 years. The symptoms, however, decrease with age. ${ }^{5}$
Bacterial and viral pathogens can cause infective conjunctivitis which can further be differentiated into acute infective conjunctivitis and chronic conjunctivitis. ${ }^{6}$ Acute infective conjunctivitis is defined as inflammation of the conjunctiva due to infection that does not last longer than three weeks, whereas chronic conjunctivitis is defined as inflammation of the conjunctiva that lasts longer than three weeks. ${ }^{6}$

\section{The atopic march}

Atopy refers to the increased sensitivity of $\lg E$ to a specific antigen, which, in turn, results in a hypersensitive response upon exposure to the specific allergen in question. 'Atopic march' is a term that refers to the development of various atopic diseases that may develop during childhood. The atopic march may also refer to how the sequence of clinical symptoms and atopic disease manifest during childhood growth and development. ${ }^{8}$ The initial development of atopy has been linked to various predisposing risk factors. These include a genetic predisposition, decreased exposure to infections and endotoxins, postnatal antibiotic use, obesity, tobacco smoke, air pollutants, exposure to allergens, maternal weight gain or obesity, gestational use of antibiotics and maternal stress. ${ }^{9}$

\section{Pathophysiology of atopy}

There is vast evidence that shows that T-lymphocytes play a major role in allergic diseases. The T-helper cell type $1\left(T_{h} 1\right) /$ T-helper cell type $2\left(T_{h} 2\right)$ paradigm has been extensively studied and seems to be the major pathological pathway in allergic diseases. The paradigm explains the relationship between the $T_{h} 1$ and $T_{h} 2$ subsets of the $T$ lymphocyte. $T_{h} 1$ and $T_{h} 2$ subsets tend to differentiate from CD4+-naïve $T$ lymphocytes. This 


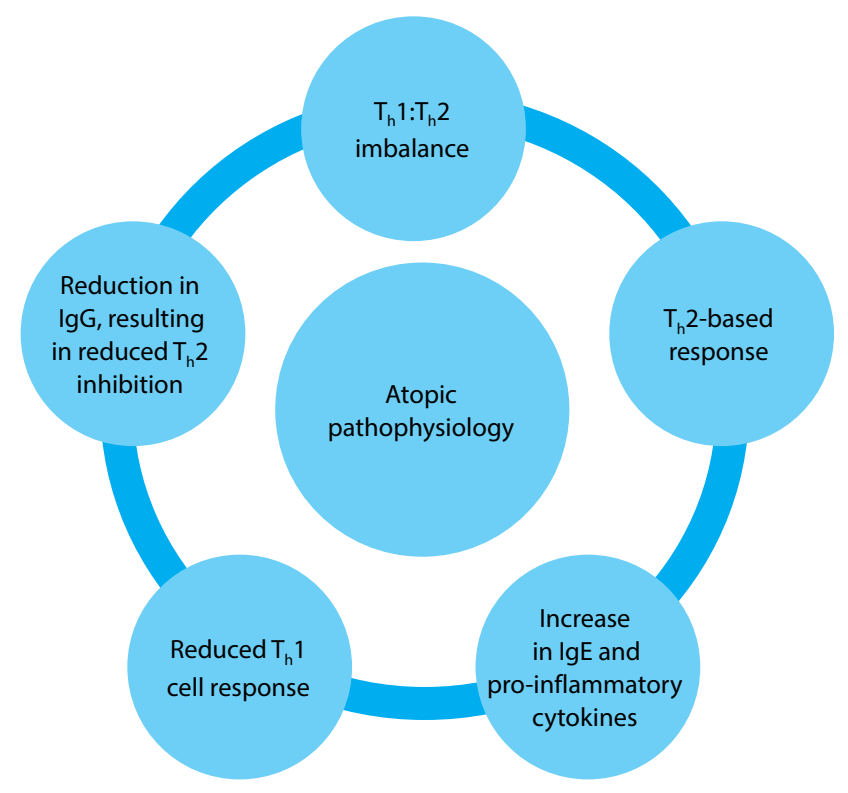

Figure 1: The imbalance between $T_{h} 1$ and $T_{h} 2$

IgG - immunoglobulin $G ; T_{h} 1-T$-helper cell type $1 ; T_{h} 2-T$-helper cell type 2

means that whenever a raised response towards either the $T_{h} 1$ or the $T_{h} 2$ subset occurs, the other will be reduced. ${ }^{10}$ When there is a reduction in $T_{h} 1$ production, there are observed decreased levels of interferon gamma (IFN-g), interleukin (IL)-2 and tumour necrosis factor (TNF)-beta. This in turn leads to elevated levels of the $T_{h} 2$ effect, owing to a decrease in IgG production, which inhibits $T_{h} 2$ formation. ${ }^{10,11}$ Figure 1 illustrates the imbalance in $T_{h} 1$ and $T_{h} 2$ that leads to atopic diseases. ${ }^{11}$

There are various risk factors that can predispose a patient towards the development of atopy - refer to Figure 2.

\section{The role of histamine in allergy}

Histamine is an endogenous substance synthesised from histidine. It has the ability to elicit autacoid effects within peripheral tissues and also acts as a neurotransmitter within the central nervous system (CNS). ${ }^{12}$ The role of histamine in the inflammatory process remains significant in understanding the pathophysiology thereof. The release of histamine in peripheral tissue areas is mediated by mast cell degranulation. This degranulation can be triggered in various ways. In allergic diseases, an interaction between IgE (immunoglobulin E) antibodies and suitable $\lg \mathrm{E}$ antigens (i.e. the formation of antigen-antibody complexes) that causes allergic reactions (localised histamine release) or anaphylaxis (systemic histamine release), seems to be the major trigger. ${ }^{12}$

There are currently four identified histaminergic receptor subtypes (i.e. the $\mathrm{H}_{1}$ to $\mathrm{H}_{4}$-receptors). The $\mathrm{H}_{1}$-receptor is the main active subtype in mediating acute allergic reactions. There are different effects that may be induced by $\mathrm{H}_{1}$-receptor stimulation. Some of these effects lead to allergic conditions, which include allergic rhinitis and conjunctivitis, urticaria, pruritus and angioneurotic oedema. ${ }^{12}$

Stimulation of these receptors is also responsible for the vasodilatation and the increased vascular (capillary) permeability that accompany allergic reactions and inflammation. Erythema and oedema, including potentially fatal glottis oedema. Understanding histamine regulation assists in the type of treatment to be initiated in various allergic reactions. For instance, histamine is released systemically in anaphylaxis but the use of an antihistamine alone is not effective in treating anaphylaxis.

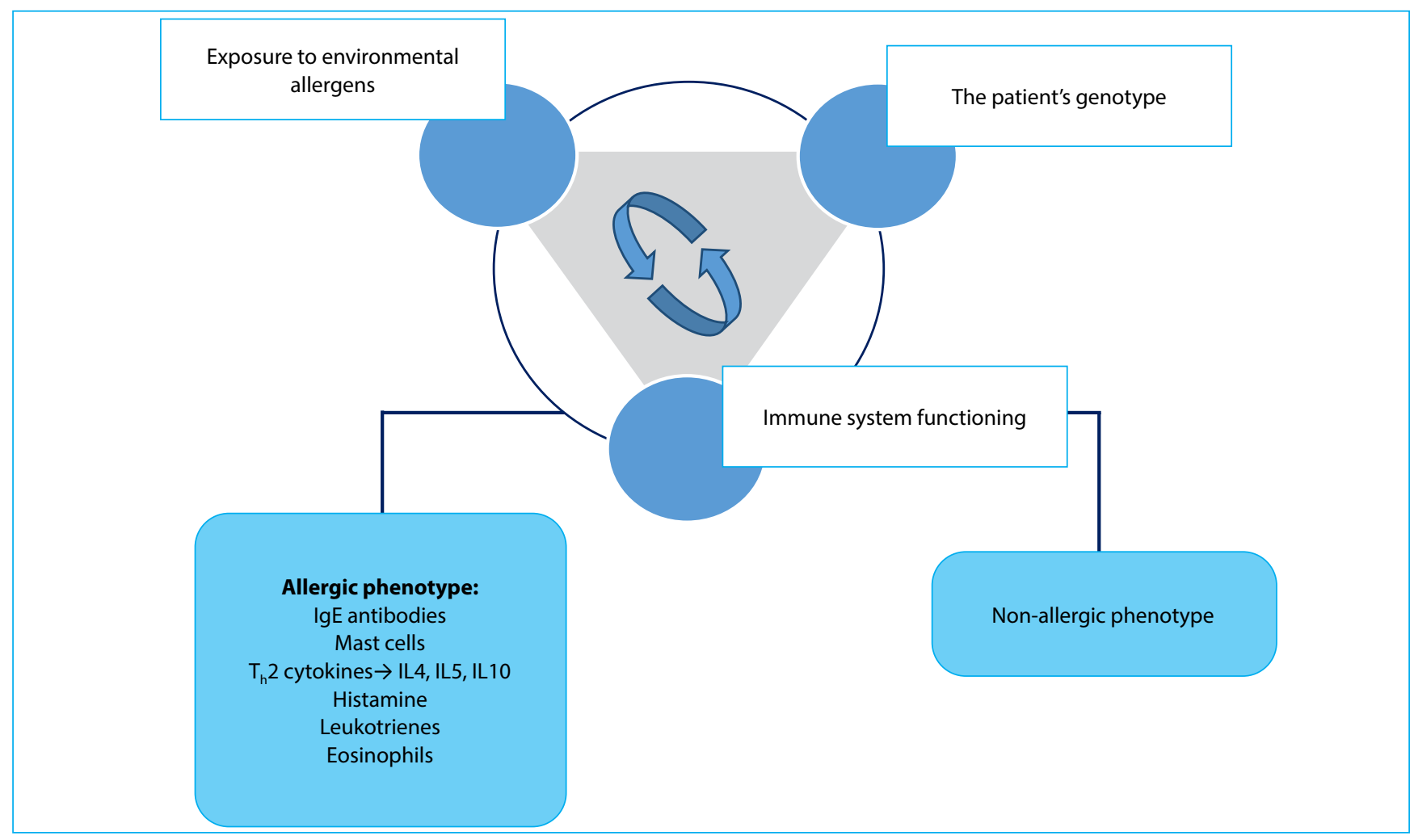

Figure 2: Risk factors for developing atopy ${ }^{2}$ 


\section{Genetic predisposition}

Allergies tend to be familial, with patients who suffer from an allergy tending to have an increased risk of having children with some form of atopy. ${ }^{2}$ There is vast evidence that shows that $\mathrm{T}$ lymphocytes play a major role in allergic diseases. Several studies have examined the role of genetics in allergic diseases. Some studies have had mitochondrial RNA (miRNA) as the main focus of such investigations. The earlier studies have shown that several types of miRNA augment the sensitivity of T cells to peptide antigens. Evidence suggests that inhibition of miR-181a expression in immature $T$ cells significantly decreases sensitivity to antigens and enhances the impairment of T-cell selection. T-cell apoptosis is crucial in regulating both the length and strength of T-cell responses. MiR-2 1 has also been extensively studied, showing significant upregulation during T-cell activation and plays a role in the suppression of apoptosis in activated T cells. It is therefore essential to understand the role of various miRNA in T-cell regulation as the development of polarised $T_{h}$ cells is central to the pathogenesis of allergic inflammation because allergic inflammation is predominately a $\mathrm{T}_{\mathrm{h}} 2$ response. ${ }^{13}$

\section{Allergen exposure}

Exposure to an allergen in individuals with an atopic disease increases the risk of developing a hypersensitivity reaction, regardless of the level of antigen exposure. The evidence showing that immune sensitisation is not dependent on the level of allergen exposure gives credibility to a belief that the existence of atopic disease is hereditary. On the contrary, low levels of allergen exposure are not sufficient to produce a response, while high levels of allergen exposure induce tolerance toward that allergen, i.e. desensitising it. ${ }^{14}$

\section{Infections and endotoxin exposure}

The hygiene hypothesis is applied in most atopic diseases. It predicts that the prevalence of atopic diseases is decreased when a child is exposed to more infectious agents. It is estimated that the exposure to animals, viruses, bacteria and various endotoxins makes children less likely to develop an atopic disease. The hygiene hypothesis emerges from the understanding that bacterial, viral and endotoxin factors trigger an immune response of $T_{h} 1$ lymphocytes. $T_{h} 1$ lymphocytes increase the production of IgG antibodies. $T_{h} 1$ (through $\lg G$ ) indirectly suppresses the activity of $T_{h} 2$ which mediates the release of various cytokines including lgE. These $\mathrm{T}_{\mathrm{h}} 2$ cytokines are common culprits in the development of allergic diseases. ${ }^{2,8,15,16}$

\section{Intestinal flora}

The presence of microbes in the walls of the intestinal tract helps to regulate an immune response. Exposure early in life to microbial flora within the gastrointestinal tract, allows for a change in the $T_{h} 1: T_{h} 2$ cytokine balance, favouring a $T_{h} 1$ cell response. A shift in the microbial balance initiates a change in immune response. ${ }^{2}$ The evidence then suggests that exposure to high dosages of antibiotics in early neonates may alter the composition of intestinal flora, leaning towards an immune response with elevated levels of $T_{h} 2$. The elevated $T_{h} 2$ leads to increased $\lg E$ production and therefore the likelihood of developing an atopic disease. ${ }^{17}$

\section{Conjunctivitis}

\section{Allergic conjunctivitis}

Allergic conjunctivitis is an inflammatory response of the conjunctivae to allergens such as pollens, environmental antigens (e.g. dust), and animal dander. ${ }^{18}$ Hyperaemic conjunctivitis is a common type of conjunctivitis; most patients show symptoms of ocular itching, lacrimation, hyperaemia, eye discharge, etc. Severe symptoms cause eyelid swelling. A number of conditions may present with conjunctivitis (red eye), but it would be best to try and differentiate allergic conjunctivitis from other eye conditions. Knowledge of eye conditions, how they present and their prevalence is important

\section{Types of allergic conjunctivitis}

Allergic conjunctivitis can be differentiated into three types: acute allergic conjunctivitis, seasonal allergic conjunctivitis (SAC), and perennial allergic conjunctivitis (PAC). The differences between these three types are demonstrated in Table I below, and before a likely diagnosis is made, the following should be considered - the causative agent involved, types of discharge, ocular symptoms and lastly, other accompanying symptoms (Table II). ${ }^{5,6}$

\section{Bacterial conjunctivitis}

Bacterial conjunctivitis has a seemingly higher incidence in paediatrics than in adult patients. Conjunctivitis is often a selflimiting illness and antibiotics should be used only in cases where bacterial conjunctivitis has been confirmed. ${ }^{6}$ It is vital that the correct diagnosis is made early so as to identify the cause and start the correct treatment promptly. ${ }^{6}$ Furthermore, it is essential to rule out more serious causes that could be classified as a

Table I: Differences between the three types of allergic conjunctivitis ${ }^{5}$

\begin{tabular}{|c|c|c|c|}
\hline Type of allergic conjuctivits & Onset & Causes & Allergens \\
\hline Acute allergic conjunctivitis & $\begin{array}{l}\text { Sudden onset, develops rapidly (within } \\
30 \text { mins) and resolves immediately in the } \\
\text { absence of the allergen (within } 24 \text { hours) }\end{array}$ & Environmental exposure & \\
\hline $\begin{array}{l}\text { Seasonal allergic } \\
\text { conjunctivitis (SAC) }\end{array}$ & $\begin{array}{l}\text { Progressive onset and occurs gradually } \\
\text { over days to weeks }\end{array}$ & Specific allergen & $\begin{array}{l}\text { Tree pollen in spring } \\
\text { Grass pollen in summer } \\
\text { Wood pollen in late summer or autumn }\end{array}$ \\
\hline $\begin{array}{l}\text { Perennial allergic } \\
\text { conjunctivitis (PAC) }\end{array}$ & $\begin{array}{l}\text { It is mild and chronic that can either } \\
\text { increase or decrease in severity }\end{array}$ & $\begin{array}{l}\text { Year round } \\
\text { environmental exposure }\end{array}$ & $\begin{array}{l}\text { Dust mites } \\
\text { Animal dander } \\
\text { Moulds }\end{array}$ \\
\hline
\end{tabular}




\begin{tabular}{|c|c|c|c|c|}
\hline \multicolumn{5}{|c|}{ Conjunctivitis } \\
\hline Infectious & Causative agent & Type of discharge & Ocular symptoms & Accompanying symptoms \\
\hline Viral & $\begin{array}{l}\text { Adenoviruses } \\
\text { (most common cause) }\end{array}$ & - Watery & - Red eye & $\begin{array}{l}\text { Pharyngoconjunctival fever } \\
\text { - High fever } \\
\text { - Pharyngitis } \\
\text { - Enlargement of the periauricular } \\
\text { lymph nodes } \\
\text { - Bilateral conjunctivitis } \\
\text { Keratoconjunctivitis (severe) } \\
\text { - Oedema of the sclera } \\
\text { - Hyperaemia }\end{array}$ \\
\hline Bacterial & $\begin{array}{l}\text { H. influenzae* } \\
\text { S. pneumoniae* } \\
\text { S. epiderrmidis } \\
\text { S. viridans } \\
\text { S. aureus } \\
\text { Moraxella catarrhalis* } \\
\text { Neisseria gonorrhoeae }\end{array}$ & - Mucopurulent/purulent & $\begin{array}{l}\text { - Red eye } \\
\text { - Oedema of the } \\
\text { sclera } \\
\text { - Pain in the eye }\end{array}$ & $\begin{array}{l}\text { - Swelling of the eyelid } \\
\text { - Mattering and sticking together of } \\
\text { the eyelids in the morning }\end{array}$ \\
\hline \multicolumn{5}{|c|}{ Non-infectious } \\
\hline Allergic & $\begin{array}{l}\text { Allergens (pollen, animal } \\
\text { dander) }\end{array}$ & - Watery & $\begin{array}{l}\text { - Red eye } \\
\text { - Itching } \\
\text { - Burning sensation } \\
\text { - Conjunctival } \\
\text { oedema }\end{array}$ & $\begin{array}{l}\text { - Swelling of the eyelid } \\
\text { - Runny nose } \\
\text { - Blurry vision }\end{array}$ \\
\hline
\end{tabular}

medical emergency which would require hospital admission. ${ }^{6}$ These cases would include bacterial keratitis, acute closed angle glaucoma, corneal abrasions and others. ${ }^{6}$

Three major categories can be included as part of bacterial conjunctivitis: hyperacute bacterial conjunctivitis, acute conjunctivitis and chronic conjunctivitis. ${ }^{6}$

- Hyperacute bacterial conjunctivitis is most commonly seen in patients affected with $N$. gonorrhoea. It normally presents with a copious purulent discharge. Prompt treatment is essential to prevent complications. ${ }^{6}$

- Acute bacterial conjunctivitis. The following organisms are implicated in the infectious origin: Staphylococcus aureus, Haemophilus influenzae, Streptococcus pneumoniae, Moraxella catarrhalis, and Chlamydia trachomatis. ${ }^{6}$

- Chronic bacterial conjunctivitis is conjunctivitis that presents with red eye and a purulent discharge that may persist for longer than a few weeks. It is usually caused by Chlamydia trachomatis. $^{6}$

The role of the healthcare worker in the management of conjunctivitis

Healthcare workers are exposed to patients that report conjunctivitis and they should be able to assess patients individually and follow a stepwise approach. Ultimately, when necessary when patients present with comorbidities, symptoms that overlap with other conditions, no response to over-the-counter treatment, contact lens users, severe signs and symptoms, these patients should be referred for specialist treatment. ${ }^{21,22}$

\section{Emerging therapies for allergic conjunctivitis}

Topical combination antihistamine/mast cell stabilisers e.g. olopatadine provide an additional, immediate relief benefit as well as long-term relief from the mast cell stabilisation. This combination also has the additional advantage of oncedaily dosing. There is a recognised need for medications that demonstrate rapid onset and a prolonged duration of action. Twenty-four-hour dosing provides maintenance therapy during symptomatic periods without any exposure to preservatives because of fewer instillations. It also promotes compliance. A higher concentration of the olopatadine (antihistamine/mast cell stabiliser) is the newest combination therapy. ${ }^{23}$ Olopatadine, when compared to sodium cromoglycate, showed that the more expensive olopatadine had fewer patient return visits. ${ }^{5}$

\section{Management of allergic conjuctivitis}

Allergic diseases can be strategically managed both nonpharmacologically and pharmacologically. ${ }^{24}$ The use of pharmacological preparations is usually preferred when nonpharmacological methods prove ineffective or insufficient in alleviating the allergic symptoms. Different pharmaceutical preparations (systemic, intranasal, topical etc.) are used depending on the symptoms and type of allergic disease..$^{25,26}$

Topical therapy consists either of combination drugs such as an antihistamine and a vasoconstrictor, or antihistamines with mast cell stabilising properties. The former is found over-thecounter; the vasoconstrictor targets the ocular redness and the antihistamine targets the allergic symptoms. An example is the tetryzoline/antazoline combination that may, however, cause increased redness for several days after use. ${ }^{5}$ The latter, that is the antihistamine with mast cell stabilising properties, has a dual mechanism of action; it blocks histamine receptors and also 
stabilises mast cells, inhibiting their degranulation which in turn limits the release of histamine, tryptase and prostaglandin $D_{2}$. They also have an effect on leukocyte activity. These drugs are dosed twice daily.

\section{Local vs systemic antihistamines in the treatment of allergic conjunctivitis}

Based on randomised trials, topical medications are more effective compared to oral therapies when used for ocular conditions. ${ }^{5}$ The systemic use of antihistamine only relieves ocular allergic symptoms partially and patients may also experience systemic adverse effects such as drowsiness and dry mouth. ${ }^{26,27}$ Therefore topical administration, especially of a combination (antihistamine/decongestant), is more effective for ocular allergic symptoms. However, in the situation where oral therapy is used, the second-generation antihistamines are preferred as they cause less sedation because of their reduced ability to cross the blood brain barrier. 26,27

\section{Local decongestants}

Local decongestants are mainly sympathomimetic drugs that stimulate $a_{1}$-adrenergic receptors producing vasoconstriction. This in turn decreases mucosal oedema and local vasodilation. ${ }^{26}$ Examples of the most commonly used drugs include xylometazoline, phenylephrine and oxymetazoline. ${ }^{26}$ Local decongestants are usually indicated to reduce acute symptoms as prolonged use can produce undesirable effects to the user. $^{23,26}$ After persistent use (usually more than five days), rebound rhinitis and conjunctivitis medicamentosa start to appear. Oxymetazoline and xylometazoline have a long-acting effect on the $a_{1}$-receptor, whereas phenylephrine has a shorter duration of action, lasting up to approximately four hours. ${ }^{23}$ The mechanisms of action of the local decongestants illustrated in Figure 3. It involves targeting the vasodilatation of the mucosal oedema (1) that causes nasal congestion the molecules of a suitable nasal decongestant (2) bind to, and stimulate adrenergic alpha 1-receptors (3) resulting in vasoconstriction and therefore alleviates the mucosal oedema, thus increasing the diameter of the nasal lumen.

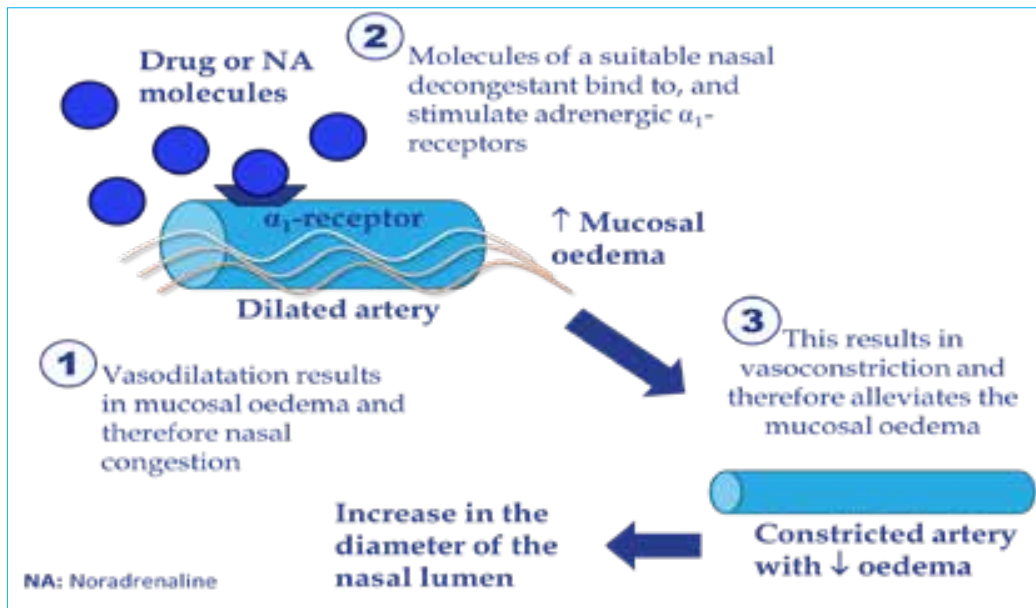

Figure 3: The mechanisms of action of the local decongestants ${ }^{26}$

\section{Systemic decongestants}

These agents stimulate $a_{1}$-receptors producing vasoconstriction, reducing oedema, redness and itching. Their preparations usually contain an antihistamine. It is important to note that combination therapy of a systemic decongestant and an oldertype $\mathrm{H}_{1}$-antihistamine can produce drowsiness and a lack of motor coordination. Systemic decongestants available in South Africa include pseudoephedrine, phenylpropanolamine and phenylephrine. The use of phenylpropanolamine has produced sub-arachnoid bleeding with a haemorrhagic stroke in women using it as an appetite suppressant. The total daily dosage of phenylpropanolamine should not exceed a $100 \mathrm{mg} .^{23,26}$

\section{Corticosteroids}

Glucocorticosteroids can be used for various allergic conditions such as asthma, allergic rhinitis and minimal use in allergic conjunctivitis. They exert their pharmacological action by modifying protein synthesis through regulating transcription, and indirectly by modifying the activity or halflife of transcription factors and mRNA. The currently available intranasal corticosteroids include: beclomethasone, budesonide, fluticasone, mometasone, triamcinolone and ciclesonide. The newer agents, namely mometasone, fluticasone, and ciclesonide, are also administered intranasally and result in minimal systemic effects. $^{27,28}$ The most common local side-effects experienced with the intranasal corticosteroids include dryness, stinging, burning, and epistaxis. Chronic use of topical corticosteroids may lead to atrophy of the nasal mucosa. It is therefore advisable to use these agents for the shortest time possible to prevent unpleasant adverse effects associated with long-term use. ${ }^{28}$ Systemic corticosteroids such as hydrocortisone and prednisone can be used in chronic dermatitis to reduce frequency of allergic flares. ${ }^{28}$

\section{The $\mathrm{H}_{1}$-antihistamines}

$\mathrm{H}_{1}$-antihistamines based on pharmacological classification, are grouped into different generations. This system of classification is based on their target receptors as well as side-effect profile. ${ }^{31}$ The $\mathrm{H}_{1}$-antihistamines are classified into first generation (older, sedating multi-potent blockers) and second generation (non-sedating, newer) antihistamines. Firstgeneration antihistamines include promethazine, chlorpheniramine, dexchlorpheniramine and cyclizine whilst the second-generation antihistamines include cetirizine (and levocetirizine), loratadine, ebastine, fexofenadine and mizolastine. The most significant difference (refer to Table III) between the two classes is that first-generation $\mathrm{H}_{1}$ antihistamines have the ability to cross the bloodbrain barrier and the second-generation nonsedating $\mathrm{H}_{1}$-antihistamines have very limited ability, if none at all, to cross the blood-brain barrier. It is also important to note that two generations of systemic (oral and/or parenteral) agents, topical (including intranasal and ophthalmic) $\mathrm{H}_{1}$-antihistamines are available as well. ${ }^{29-33}$ 


\section{First-generation $\mathrm{H}_{1}$-antihistamines}

These older $\mathrm{H}_{1}$-receptor blockers have been shown to have sedative and multi-potent receptor blocking abilities. Their ability to cross the blood-brain barrier distinguishes them from the newer generation $\mathrm{H}_{1}$ - antihistamines. The chemical structure of the first-generation antihistamines permits them to have a certain degree of non-selectivity, exerting antagonistic effects of an antimuscarinic or anticholinergic, antihistaminergic, $a_{1}$-adrenergic blocking, anti-serotonergic and local anaesthetic nature. Because of their wide range of receptor blocking, the first-generation $\mathrm{H}_{1}$-antihistamines have a variety of indications and uses, which range from allergies and rhino-conjunctivitis, to nausea and vomiting, motion sickness and insomnia. Their effects on multiple receptors, on the other hand, also have undesirable effects (refer to Table IV) and are not recommended for use in patients who suffer from glaucoma, benign prostatic
Table IV: The adverse effects of first-generation $\mathrm{H}_{1}$-antihistamines, as reflected by receptor activity ${ }^{29-33}$

\begin{tabular}{ll}
\hline $\begin{array}{l}\text { Receptor } \\
\text { antagonistic } \\
\text { interaction }\end{array}$ & Side-effects \\
\hline $\begin{array}{l}\mathrm{H}_{1} \text { receptor } \\
\text { Muscarinic receptor }\end{array}$ & $\begin{array}{l}\text { A reduction in central nervous system } \\
\text { neurotransmission, sedation, reduced } \\
\text { cognitive and neuro-psychomotor } \\
\text { performance, and an increased appetite }\end{array}$ \\
\hline $\begin{array}{l}\text { X-adrenergic } \\
\text { tachycardia }\end{array}$ \\
\hline $\begin{array}{l}\text { Seceptor } \\
\text { receptonergic }\end{array}$ & $\begin{array}{l}\text { QTC-interval prolongation and ventricular } \\
\text { arrhythmias }\end{array}$ \\
\hline $\begin{array}{l}\text { IKr and other } \\
\text { cardiac channels } \\
\text { receptors }\end{array}$ & $\begin{array}{l}\text { An increased appetite } \\
\text { arrhythmias }\end{array}$ \\
\hline
\end{tabular}

Table III: The differences between first- and second-generation $\mathrm{H} 1$-antihistamines ${ }^{29-33}$

\begin{tabular}{|c|c|c|}
\hline & Older, first-generation $\mathrm{H}_{1}$-antihistamines & Newer, second-generation $\mathrm{H}_{1}$-antihistamines \\
\hline Drug examples & $\begin{array}{l}\text { Promethazine } \\
\text { Chlorpheniramine } \\
\text { Dexchlorpheniramine } \\
\text { Hydroxyzine } \\
\text { Cyclizine }\end{array}$ & $\begin{array}{l}\text { Cetirizine and levocetirizine } \\
\text { Loratadine } \\
\text { Ebastine } \\
\text { Fexofenadine } \\
\text { Mizolastine } \\
\text { Rupatadine }\end{array}$ \\
\hline Frequency & Usually administered in 3-4 daily dosages & Usually administered once or twice a day \\
\hline Mechanism of action & Potent blockers of $\mathrm{H}_{1}, \alpha_{1}$ and muscarinic receptors & Selective $\mathrm{H}_{1}$-receptor antagonists \\
\hline Blood-brain barrier & $\begin{array}{l}\text { Cross the blood-brain barrier (lipophilicity, low } \\
\text { molecular weight and lack of recognition by the } \\
\text { p-glycoprotein efflux pump) }\end{array}$ & $\begin{array}{l}\text { Generally, do not cross the blood-brain barrier at } \\
\text { recommended dosages (lipophobicity, high molecular } \\
\text { weight and recognition by the } p \text {-glycoprotein efflux pump) }\end{array}$ \\
\hline \multirow{3}{*}{ Indications } & $\begin{array}{l}\text { The options for sedation include hydroxyzine, } \\
\text { promethazine and diphenhydramine. However, more } \\
\text { suitable agents may be used in the management of } \\
\text { insomnia }\end{array}$ & $\begin{array}{l}\text { Fexofenadine has the shortest half-life of the systemic } \\
\text { agents. Furthermore, it also does not display any } \mathrm{H}_{1} \text {-receptor } \\
\text { occupancy inside the central nervous system at therapeutic } \\
\text { dosages }\end{array}$ \\
\hline & $\begin{array}{l}\text { As an antiemetic agent, choose from cyclizine } \\
\text { (syn. meclizine), diphenhydramine, hydroxyzine } \\
\text { or promethazine, for example. First-generation } \\
\mathrm{H}_{1} \text {-antihistamines may be very useful in the } \\
\text { management of postoperative nausea and vomiting, as } \\
\text { well as vertigo }\end{array}$ & $\begin{array}{l}\text { Cetirizine has the greatest likelihood of displaying some } \\
\text { degree of } \mathrm{H}_{1} \text {-receptor occupancy inside the central nervous } \\
\text { system, which may result in some level of sedation, albeit at } \\
\text { higher-than-recommended dosages }\end{array}$ \\
\hline & $\begin{array}{l}\text { Chlorpheniramine displays lower levels of sedation than } \\
\text { many of the other examples in this group, and may } \\
\text { therefore be better suited to the management of allergic } \\
\text { reactions }\end{array}$ & $\begin{array}{l}\text { Rupatadine fumarate is approved for the treatment of allergic } \\
\text { rhinitis and chronic urticaria for adults and children aged } 12 \\
\text { years and older }\end{array}$ \\
\hline
\end{tabular}

Potentially cause side-effects, such as:

Sedation

Drowsiness and dizziness

Hyperactivity (meta-reaction)

Insomnia

Convulsions

Side-effects

Impaired driving performance

Fatigue and lassitude (well documented)

Do not cause side-effects (sedation, fatigue, hyperactivity and convulsions) in the absence of drug interactions

Anticholinergic side-effects, including a dry mouth, urinary retention, gastrointestinal upset and appetite stimulation

Minor side-effects include:

Nausea

Light headedness

Drowsiness

Headaches

Agitation and a dry mouth 
hyperplasia and in cardiac patients (i.e. ischaemic heart disease, myocardial infarction and congestive heart failure). ${ }^{29-33}$

The following drugs in this group are of note:

- The options include hydroxyzine, promethazine and diphenhydramine. These drugs are used in the management of insomnia but there are more suitable agents that may be used.

- Cyclizine (syn. meclizine), diphenhydramine, hydroxyzine or promethazine, are examples of antiemetic agents. Firstgeneration $\mathrm{H}_{1}$-antihistamines may be very useful in the management of postoperative nausea and vomiting, as well as vertigo.

- Chlorpheniramine is better suited for use in allergic reactions due to its relatively lower sedation levels than the other firstgeneration antihistamines.

It should be noted that these "older" drugs have never been optimally investigated and profiled from a clinical pharmacology perspective.

\section{Second-generation $\mathrm{H}_{1}$-antihistamines}

Second-generation $\mathrm{H}_{1}$-antihistamines are relatively newer antihistamines that do not possess the ability to cross the bloodbrain barrier. They also have no antiemetic, anticholinergic and central nervous system effects, unlike the first-generation antihistamines. Drugs like fexofenadine are actively transported into the lumen of the gut, kidney and brain by p-glycoproteins, which restrict their ability to accumulate and cause unwanted side-effects. However, agents such as rifampicin, which induce p-glycoprotein, may increase the clearance of fexofenadine and reduce their efficacy. ${ }^{34}$ Second-generation $\mathrm{H}_{1}$-antihistamines are mostly dosed once daily with minimal risk of developing tolerance. The long-term safety of the second-generation $\mathrm{H}_{1}$-antihistamines (cetirizine, desloratadine, fexofenadine, levocetirizine, and loratadine) has been documented in randomised controlled trials lasting 6-18 months in adults, and in children as young as $1-2$ years' old. ${ }^{35}$

Ophthalmic (eyedrop) preparations include levocabastine, epinastine, olopatadine and ketotifen (Olopatadine and ketotifen also act as mast cell stabilisers). Levocabastine, in addition to azelastine, is also available as a nasal spray for use in patients who suffer from allergic rhinitis. ${ }^{36}$

Rupatadine fumarate is a newly launched, second-generation, long-acting histamine antagonist ( $\mathrm{H}_{1}$-receptor antagonist) and platelet-activating factor receptor inhibitor. Rupatadine fumarate is approved for the treatment of allergic rhinitis and chronic urticaria in adults and children aged 12 years and older. It inhibits the degranulation of mast cells and the subsequent release of cytokines, more specifically of tissue necrotising factor which is available in mast cells and monocytes. ${ }^{37}$

\section{The leukotriene-receptor antagonists}

Examples of leukotriene receptor antagonists include zafirlukast and montelukast. They are competitive antagonists of the cysteinyl leukotriene receptor-1 (cysLT-1). They have the advantage of oral administration. Montelukast is also available as a sprinkle and in a chewable tablet form for the convenient use in paediatrics. Montelukast presents an additional option in the management of seasonal allergic rhinitis in children with asthma. ${ }^{12,23}$

\section{Mast cell stabilisers}

They act by stabilising mast cells thus preventing the release of histamine. The maximum effect is reached after 5-14 days administration and they are dosed more frequently than topical antihistamines i.e. four times daily. Therefore, they are not used in the treatment of acute allergic conjunctivitis and they are reserved for the treatment of SAC in patients that cannot tolerate other therapy. ${ }^{5}$ Lodoxamide is a mast cell stabiliser indicated for atopic conjunctivitis, vernal conjunctivitis, giant papillary conjunctivitis and allergic conjunctivitis.

\section{Management of bacterial conjunctivitis}

Acute bacterial conjunctivitis is often a self-limiting condition however when specifically indicated, patients treated early (within day 2-5) with topical antibiotics may have improved clinical outcomes. ${ }^{6}$

The majority of uncomplicated acute bacterial conjunctivitis cases are treated by clinicians with empirical topical antibiotics at diagnosis. There are several other treatment options available that include: ${ }^{6}$

- delaying treatment for five days and then beginning treatment if no sign of improvement is observed, and

- treating patients who have clinical features associated with a bacterial cause.

- Studies comparing the effectiveness of different antibiotics recommended for use in suspected bacterial conjunctivitis have shown similar levels of effectiveness. Therefore, it is important to consider local bacterial resistance and costeffectiveness of the antibiotics being prescribed. All antibiotic courses should be taken for 7-10 days. Compliance with the length of time the antibiotics are prescribed for is particularly important to help prevent the development of resistance.

The first-line treatment in mild to moderate bacterial conjunctivitis is tobramycin. In moderate to severe infections, or antibiotic-resistant infections, and in immunocompromised patients, fluoroquinolones are recommended. ${ }^{6}$ These include ofloxacin, ciprofloxacin, moxifloxacin and gatifloxacin. Chlamydial conjunctivitis requires oral antibiotics together with a topical antibiotic to treat the infection. ${ }^{6}$ The oral antibiotic options include azithromycin, doxycycline, or erythromycin. In addition, patients should be advised to take several precautions to help prevent spread of the infection. Patients should wash their hands regularly and thoroughly, especially after touching any infected secretions. Furthermore, patients should avoid sharing towels, pillows, or utensils. ${ }^{6}$

\section{Conclusion}

The incidence of conjunctivitis seems to be on a constant rise and affects a large percentage of the population. Allergic 
and bacterial conjunctivitis can decrease quality of life and productivity and can be exacerbated by the presence of comorbid conditions such as rhinitis. A stepwise approach to treatment should be taken. The topical antihistamines/mast-cell stabiliser formulations are the first treatment approach because of their ability to relieve symptoms rapidly, and because they are suitable and well-tolerated for long-term use. However, the development of newer drugs with prolonged duration of action and specificity provides more options to the prescriber.

\section{References}

1. Tamari M, ShotaTanaka, Hirota T. Genome-wide association studies of allergic diseases. Allergology International. 2013;62(1):21-28. https://doi.org/10.2332/ allergolint.13-RAl-0539.

2. Van der Poel L, Warner J. Paediatric allergy in review. Paediatrics and Child Health. 2012;22(7):259-263. https://doi.org/10.1016/j.paed.2012.02.002.

3. Prescott SL. Early-life environmental determinants of allergic diseases and the wider pandemic of inflammatory noncommunicable diseases. Journal of Allergy and Clinical Immunology. 2013;131(1):23-30. https://doi.org/10.1016/j. jaci.2012.11.019.

4. Akdis M, Akdis CA. Mechanisms of allergen-specific immunotherapy: Multiple suppressor factors at work in immune tolerance to allergens. Journal of Allergy and Clinical Immunology. 2013;133(3):621-631. https://doi.org/10.1016/j. jaci.2013.12.1088.

5. Vally $M$, Irhuma MOE. Allergic conjunctivitis. South African Family Practice. 2017;59(5):5-10. https://doi.org/10.4102/safp.v59i5.4744.

6. Azari AA, Barney NP. (2013). Conjunctivitis: A Systematic Review of Diagnosis and Treatment. JAMA. 2013;310(16):1721-1730. https://doi.org/10.1001/ jama.2013.280318.

7. Bieber T. Atopic dermatitis. Ann Dermatol. 2010;22(2):125-137. http://dx.doi. org/10.5021/ad.2010.22.2.125.

8. Leyva-Castillo J, Li M. Thymic stromal lymphopoietin and atopic diseases. Revue Francaise d'Allergologie. 2014;54(5):364-376. https://doi.org/10.1016/j. reval.2014.02.183.

9. Castro-Rodriguez JA, Forno E, Rodriguez-Martinez $C E$, Celedón JC. Risk and protective factors for childhood asthma: what is the evidence? The Journal of Allergy and Clinical Immunology: In Practice. 2016;4(6):1111-1122. https://doi. org/10.1016/j.jaip.2016.05.003.

10. Sinigaglia F, D'Ambrosio D, Rogge L. Type I interferons and the Th1/Th2 paradigm. Developmental and Comparative Immunology. 1999;23(7-9):657-663. https://doi.org/10.1016/S0145-305X(99)00039-7.

11. Alvarez Zallo N, Aguinaga-Ontoso I, Alvarez-Alvarez I, Guillén-Grima F, Azcona San Julian C. The influence of gender and atopy in the relationship between obesity and asthma in childhood. Allergologia et Immunopathologia. 2017;45(3):227-233.

12. Brunton L, Chabner B, Knollman B. (Editors). Goodman and Gilman's the pharmacological basis of therapeutics. Twelth Edition. New York:McGraw-Hill Medical Publishing Division. 2011.

13. LuTX, Rothenberg ME. Diagnostic, functional, and therapeutic roles of microRNA in allergic diseases. Journal of Allergy and Clinical Immunology. 2013;132(1):313. https://doi.org/10.1016/j.jaci.2013.04.039.

14. Tang R-B, Chang J-K, Chen H-L. Can probiotics be used to treat allergic diseases? Journal of the Chinese Medical Association. 2015;78(3):154-157. https://doi. org/10.1016/j.jcma.2014.08.015.

15. Marko M, Pawliczak R. The role of microbiota in allergy development. Alergologia Polska - Polish Journal of Allergology. 2017;4(2):58-62. https://doi. org/10.1016/j.alergo.2017.03.002.
16. Strachan DP. Hay fever, hygiene, and household size. British Medical Journal. 1989;299(6710):1259-1260. https://doi.org/10.1136/bmj.299.6710.1259.

17. Brown EM, Arrieta M-C, Finlay BB. A fresh look at the hygiene hypothesis: How intestinal microbial exposure drives immune effector responses in atopic disease. Seminars in Immunology. 2013;25(5):378-387. https://doi.org/10.1016/j. smim.2013.09.003.

18. Bielory BP, O'Brien TP, Bielory L. Management of seasonal allergic conjuctivitis: guide to therapy. Acta Ophthalmologica. 2012;90(5):399-407. https://doi. org/10.1111/j.1755-3768.2011.02272.x.

19. Davis $S$. Topical treatment options for allergic conjunctivitis, South African Family Practice. 2015;57(4):10-15.

20. Haahtela T, Holgate S, Pawankar R, et al. Special Committee on Climate Change and Biodiversity. The biodiversity hypothesis and allergic disease:world allergy organization position statement. World Allergy Organization Journal. 2013;6(3):1-19. https://doi.org/10.1186/1939-4551-6-3.

21. Albrecht S. Conjunctivitis. US Pharm. 2011;36(4):29-34.

22. Bielory L, Meltzer EO, Nicholas KK, Melton R, Thomas RK, Bartlett JD. 2013. An algorithm for the management of allergic conjunctivitis. Allergy Asthma Proc. 2013;34(5):408-420. https://doi.org/10.2500/aap.2013.34.3695.

23. Rossiter D, editor. South African Medicines Formulary. 11th ed. Cape Town: Health and Medical Publishing Group; 2014.

24. Carr W, Schaeffer J, Donnenfeld E. Treating allergic conjunctivitis: A once-daily medication that provides 24-hour symptom relief. Allergy and Rhinology (Providence Rl), 2016;7(2):107-114. https://doi.org/10.2500/ar.2016.7.0158.

25. Trubo R. Seasonal ocular allergy: new options for a recurring problem. Cornea. 2015 Mar:31-3.

26. Schellack G. Pharmacology in clinical practice: application made easy for nurses and allied health professionals. 2nd edition. Claremont: Juta and Co Ltd. 2010.

27. National Department of Health, South Africa. 2019. Essential Medicines List and Standard Treatment Guidelines App. Version 2.7 (148). Content version 1095

28. Derendorf $\mathrm{H}$, Meltzer EO. Molecular and clinical pharmacology of intranasal corticosteroids: clinical and therapeutic implications. Allergy. 2008;63(10):12921300. https://doi.org/10.1111/j.1398-9995.2008.01750.x.

29. Sadek B, Stark H. Cherry-picked ligands at histamine receptor subtypes. Neuropharmacology. 2017;106:56-73. https://doi.org/10.1016/j. neuropharm.2015.11.005.

30. Rondón C, Campo P, Togias A, et al. Local allergic rhinitis: concept, pathophysiology, and management. J Allergy Clin Immunol. 2012;129(6):14601467. https://doi.org/10.1016/j.jaci.2012.02.032.

31. Criado PR, Criado RFJ, Maruta CW, Filho CDM. Histamine, histamine receptors and antihistamines: new concepts. An Bras Dermatol. 2010;85(2):195-210. https://doi.org/10.1590/S0365-05962010000200010.

32. Potter PC. Effectiveness and safety of new generation antihistamines in allergenic rhinitis and urticaria. S Afr Fam Pract. 2004;47(1):24-28. https://doi. org/10.1080/20786204.2005.10873256.

33. Simons FER, Simons KJ. Histamine and $\mathrm{H} 1$-antihistamines: celebrating a century of progress. J Allergy Clin Immunol. 2011;128(6):1139-1150. https://doi. org/10.1016/j.jaci.2011.09.005.

34. Williams P, Crandall E, Sheppard JD. Azelastine hydrochloride, a dual-acting anti-inflammatory ophthalmic solution, for treatment of allergic conjunctivitis. Clin Ophthalmol. 2010;4:993-1001. https://doi.org/10.2147/OPTH.S13479.

35. Mullol J, Bousquet J, Bachert C, et al. Rupatadine in allergic rhinitis and chronic urticaria. Allergy. 2008;63(Suppl 87):5-28. https://doi. org/10.1111/j.1398-9995.2008.01640.x.

36. Ventocilla M, Bloomenstein MR, Majmudar PA. 2018. Allergic conjunctivitis treatment and management. Medscape. Accessed 31 March 2020. Available from: https://emedicine.medscape.com/article/1191467-treatment.

37. Shamizadeh S, Brockow K, Ring J. Rupatadine: efficacy and safety of a non-sedating antihistamine with PAF-antagonist effects. Allergo J Int. 2014;23(3):87-95. https://doi.org/10.1007/s40629-014-0011-7. 